\title{
CORRECTION
}

\section{Correction to: Discharge hydraulic behavior comparison of two karstic springs in Kuhe-Safid anticline, Khuzestan, Iran}

\author{
N. Kalantari ${ }^{1} \cdot$ H. Rouhi ${ }^{1}$
}

Published online: 12 March 2019

c) Springer-Verlag GmbH Germany, part of Springer Nature 2019

Correction to: Carbonates and Evaporites

https://doi.org/10.1007/s13146-018-0427-0

The original version of this article unfortunately contained a mistake. The correct affiliation of the authors should be:

Department of Geology, Faculty of Earth Sciences, Shahid Chamran University of Ahvaz, Ahvaz, Iran

Publisher's Note Springer Nature remains neutral with regard to jurisdictional claims in published maps and institutional affiliations.

The original article can be found online at https://doi.org/10.1007/ s13146-018-0427-0.

N. Kalantari

nkalantari@hotmail.com

1 Department of Geology, Faculty of Earth Sciences, Shahid Chamran University of Ahvaz, Ahvaz, Iran 